\title{
Reproductive status of cows slaughtered at the Ngaoundere Municipal Slaughter House and factors responsible for potential losses in herd productivity
}

\author{
G.S. BAH ${ }^{1 *}$, A.L. EBANGI ${ }^{2}$, E.S. NIBA ${ }^{1}$, T.K. MANCHANG ${ }^{1}$, O. MESSINE ${ }^{1}$ and \\ M.D. ACHUKWI ${ }^{1}$ \\ ${ }^{l}$ Regional Centre of Agricultural Research for Development, Wakwa, P.O. Box 65 Ngaoundere, Cameroon. \\ ${ }^{2}$ Regional Centre of Agricultural Research for Development, Bambui, P.O. Box 51 Bamenda, Cameroon. \\ * Corresponding author, E-Mail: bahsohg2002@yahoo.com
}

\begin{abstract}
The reproductive status (RS) of 2,103 cows slaughtered at the Ngaoundere Municipal Slaughter House (NMSH) in view of highlighting potential losses resulting from the slaughtering of pregnant cows (PC) were assessed. Concurrently, 390 of the cows evaluated for RS were randomly selected for a detailed identification of the possible causes of infertility from the gross reproductive pathologies (GRP) observed in the reproductive tract. Data were collected between July and December, 2004 and analyzed using SAS program (1991). Of a sample of 2,426 animals slaughtered, 2,103 (86.6\%) were cows. The prevalence of PC slaughtered was 37.3\%. Majority $(83 \%)$ of the cows slaughtered were below 9 years of age. The PC slaughtered (7.5 years) were significantly $(\mathrm{p}<0.001)$ older than that of the non PC (6.9 years). Thirty-three percent of the slaughtered cows were infertile. The common GRP observed were ovarian inactivity (24.8\%), metritis $(5.1 \%)$ and vaginometritis $(0.8 \%)$. Although the prevalence of metritis was found very low, it may be useful to identify its causes together with those of ovarian inactivity which were the principal factors that justify the slaughter of some cows below 9 years in the Region. However, there is need to check for pregnancy in all cows before slaughtering in all national abattoirs to minimise economic losses related to pregnancy losses and to contribute to the growth of the cattle industry.

(C) 2010 International Formulae Group. All rights reserved.
\end{abstract}

Keywords: Pregnant Cow, Metritis, Fetus, Ovarian inactivity, Reproductive Pathology, Cameroon

\section{INTRODUCTION}

In Cameroon, cattle represent $16 \%$ of the national agricultural production and supplies $61 \%$ of the national meat demands (Ebangi et al. 2000). The Adamawa Region has $38 \%$ of the more than 5.5 million cattle head in Cameroon (MINEPIA, 2003), with major cattle breeds being the Gudali, Aku
(Red Fulani) and Djafon. These breeds are characterized by low productivity, delayed age at first calving of average 54 months and long calving interval of 536 days (Messine, 2003). The management system is extensive and with environmental constraints abound, the animals are often exposed to various types of diseases such as Foot and Mouth Disease (FMD), 
Trypanosomosis, Black-Quarters, LumpingSkin-Disease and abortions (Awa and Achukwi, 2010; MINEPIA, 2003).

The slaughter of pregnant cows (PC) and cows below 9 years of age is prohibited at all abattoirs in Cameroon because it is a major cause in the decline of cattle population and therefore, constitutes a real menace to the country's food security. However, $16.61 \%$ and $22 \%$, of bovine slaughtered at the Yaoundé (Tchoumboue, 1984) and Bamenda (Ndi et al., 1993), abattoirs were pregnant. Ndi et al. (1993) showed that the slaughtering of pregnant cows decreased national cattle productivity by $2.5 \%$ with economic losses estimated at 4.11 billions of dollars. The total loss of livestock of $27.1 \%$, either because of high mortalities, sales and slaughter of pregnant animals is above population increase estimated at $23 \%$, causing a net population decrease by $4.1 \%$ (Ndi et al., 1993). This annual negative trend, if not checked, will in the long term threaten the sustainability of the livestock industry in Cameroon.

Poor herd management, absence of diagnosis of pregnancy before slaughter and attractive prices on pregnant cows are some major reasons for the slaughter of pregnant animals (Ndi et al., 1993; Tchoumboue, 1988; Tchoumboue, 1989). Infertility or sterility is an important factor that can lead to the sales of animals, especially cows, at productive age for slaughtering. It can be caused by infection, poor nutrition, poor management and/or anatomical defects of the reproductive organs (Hafez, 1986; Hansen, 2004). The infectious causes are often clinically characterized by repeat breeding due to early embryonic deaths and abortions while the non infectious causes are characterized clinically by anoestrus or nymphomania. Related information is lacking for the Adamawa region, which harbours approximately $38 \%$ of the national cattle herd. Information on the role of infertility and choice of animals to be culled is also lacking. The objectives of this study are therefore, to determine the prevalence of pregnant cows slaughtered and reasons for the slaughtering cows of productive age. It also seeks to identify gross pathologies and physiological abnormalities found in the reproductive tracts and organs of cows slaughtered at the Ngaoundere Municipal Slaughter House (NMSH).

\section{MATERIALS AND METHODS Animals studied}

A total of 2,426 cattle aged two to 14 years were used for the study. Of these 2,103 $(86 \%)$ of total were females with $76.5 \%$, $3.3 \%, 1.1 \%, 11.5 \%$ and $7.6 \%$ of them being Gudali, Djafun, Aku, Gudali x Exotic crosses and Gudali x Djafun crosses, respectively. All the animals slaughtered at the NMSH were purchased from the cattle market supplied by farmers in the Vina Division.

\section{Slaughtering procedures}

In a day, an average of 51 animals were slaughtered. Animals destined for slaughter were brought in the evening and enclosed at the former Ngaoundere Cattle Market, situated at $1 \mathrm{~km}$ from the NMSH. Slaughter was carried out the next day as from 6 a.m., after which all the carcasses were cut into parts, with the liver, lungs and the heart put apart in readiness for inspection by the animal health officers.

\section{Sampling technique}

A simple random sampling technique was used to select the days of visit to the slaughter house ( $\mathrm{SH}$ ) from a list of the seven days spanning from Monday to Sunday. Two days were selected per week to make up the 40 days of visit made to the abattoir from July to December 2004. All the female cattle slaughtered on each day of visit to the NMSH were used in the identification of reproductive status from the 2,103 females cattle slaughtered. Cluster sampling technique was used to conduct a concurrent detailed study of the gross reproductive pathologies (GRP) and other abnormalities of reproduction in the reproductive tracts of the slaughtered cows. To permit a better follow up of cases, 10 cows 
were randomly selected from one half of the $\mathrm{SH}$ per day while alternating sides of the $\mathrm{SH}$ during the 40 days of visit. A total of 390 cows from the 2,103 cows slaughtered were selected for the evaluation of the prevalence of infertility amongst the slaughtered cows.

\section{Identification of reproductive status}

Pregnancy was identified from the presence of fetus or embryo from an enlarged uterus while the ovaries from the non pregnant cows (NPC) were observed for the presence of follicles in order to establish their fertility status. The breed, age and body condition score of each cow slaughtered were noted. The age was determined from changes in dentition as described by Mertens (1987) and the body condition score noted on a score from 1 to 5 . The crown to rump length of the foetus was measured with a measuring tape and used to estimate foetal age as described by Noakes (1986).

\section{Identification of reproductive pathology}

After slaughter, each selected animal was first examined for the presence of the reproductive tract. Cows with developed reproductive tracts were examined for GRP. The pathologies in search for, were based on the presence or absence of signs of inflammation on the uterus (metritis) or the vagina (vaginitis) and signs of abnormal swelling. Physiological abnormalities of the reproduction were detected from changes on the ovaries. The absence of follicles or corpus luteum on the ovary in the presence of corpus albicans only indicated ovarian inactivity in cows that had previously conceived. This condition is clinically known as anoestrus. Undeveloped uteri and ovaries, common mostly in heifers will also have inactive ovaries. Repeated ovulation without conception often leaves behind traces that are visible on the ovaries. The presence of an active corpus luteum accompanied by 2 to 9 regressing corpora lutea or red spots of diameter 2 to 4 $\mathrm{mm}$ represented cows with the repeat breeder syndrome.

\section{Data analysis}

The prevalence of pregnancy and reproductive pathologies were estimated and Chi square analysis was used to test whether observed differences between sample proportions were significant or were simply attributed to chance (SAS, 1991). The average number of animals slaughtered in a day and the number of foetuses recuperated were calculated and used for the projection of the respective number of animals and pregnant cows slaughtered in a year.

\section{RESULTS}

\section{Pregnant cows slaughtered}

Of the 2,103 cows involved in the study, $779(37.3 \%)$ of the slaughtered cows were pregnant (Table 1) and $4.9 \%$ had a doubtful status. These were cows whose uteri were engorged, each having a prominent corpus luteum but without an embryo in the uterus. Their embryos might either have been crush by the butchers, while excising the uterus from the abdominal cavity or the embryos had degenerated. There was a significant difference $(\mathrm{P}<0.001)$ in the distribution of pregnant cows (PC) slaughtered between July (rainy season) and October and December (dry season) (Table 2). The highest proportion of slaughtered PC (162) was registered in the month of November. The effects of sex, status of the cow, the health status and the month during which the animal was slaughtered were significantly $(p<0.001)$ important (Table 2).

\section{Age and reproductive state of slaughtered cows}

The average age of slaughtered cows was $7.18 \pm 0.33$ years and $83 \%$ of slaughtered cows were at least 9 years of age. Slaughtered $\mathrm{PC}$, aged $7.48 \pm 0.76$ years were significantly $(\mathrm{P}<0,001)$ older than the NPC $(6.94 \pm 0.70$ years). Majority of NPC slaughtered were cyclic and hence fertile, though $4.9 \%$ had questionable status (Figure 1). The estimated age of foetus in cows slaughtered indicated that $50.1 \%, 33.7 \%$ and $16.2 \%$ of the 779 
foetuses recuperated were in their first, second and third trimester of pregnancy. A greater proportion of foetuses were two to five months of age (Figure 2). One case of twin and one of triplet pregnancy were observed. Based on the duration of the study, it was estimated that 17,250 animals were slaughtered at the NMSH in 2004, of which 6,606 were pregnant.

\section{Reproductive pathologies observed}

Of the 390 slaughtered cows examined for GRP and other abnormalities, 39.9\% had pathological problems (Table 3). Important GRP observed were: anoestrous (24.8\%), metritis $(5.1 \%)$, vagino-metritis $(0.8 \%)$ and undeveloped uterus $(0.5 \%)$. Abnormalities such as foetal maceration, scoliosis and mummification were observed and recorded simply as metritis associated with pregnancy. Most (110) of the cows with GRP were older than 7 years. Those with metritis were older than those with repeat breeder syndrome even though there was no significant difference
$(\mathrm{P}>0.05)$ in their body condition scores (Table $3)$. The mean age of heifers slaughtered was $4.03 \pm 0.39$ years and ranged from 2 to 9 years of age. A significant health effect was observed amongst the cows slaughtered indicating that the reproductive disorders are important factors influencing the slaughter of cows at the NMSH. Globally $37.3 \%$ of the 390 cows slaughtered were infertile.

\section{Relation between reproductive status and pathologies}

The observed reproductive pathologies were found in pregnant and non pregnant cows. Pathologies associated with pregnant cows were essentially metritis $(7 \%)$ and other pathologies (5.1). Metritis and the phenomenon of «repeat breeders» were found mostly in cows of doubtful status, while non cyclic cows were associated to either metritis or 'repeat breeders' pathology (Table 3)

Table 1: Distribution of slaughtered cows by month and pregnancy status.

\begin{tabular}{llll}
\hline Month & $\begin{array}{l}\text { Number of cows } \\
\text { slaughtered }\end{array}$ & $\begin{array}{l}\text { Number of } \\
\text { pregnant cows }\end{array}$ & $\begin{array}{l}\text { Prevalence of pregnant } \\
\text { cows (\%) }\end{array}$ \\
\hline July & 338 & 78 & 23.1 \\
August & 309 & 104 & 33.7 \\
September & 363 & 156 & 43.0 \\
October & 336 & 157 & 46.7 \\
November & 425 & 162 & 38.1 \\
December & 332 & 122 & 36.7 \\
July - December & 2,103 & 779 & 37.3 \\
\hline
\end{tabular}


Table 2: Factors affecting slaughter of pregnant cows at the NMSH.

\begin{tabular}{|c|c|c|}
\hline Effect & Number & Distribution (\%) \\
\hline \multicolumn{3}{|l|}{ Category ** } \\
\hline - Pregnant cow & 779 & 32.1 \\
\hline - Non pregnant cow & 1324 & 54.6 \\
\hline - $\quad$ Male & 324 & 13.3 \\
\hline \multicolumn{3}{|c|}{ Month * (all animals slaughtered) } \\
\hline - July & 402 & 16.6 \\
\hline - $\quad$ August & 372 & 15.3 \\
\hline - September & 421 & 17.4 \\
\hline - October & 389 & 16.0 \\
\hline - November & 468 & 19.3 \\
\hline - December & 374 & 15.4 \\
\hline \multicolumn{3}{|l|}{ Month x Category ** } \\
\hline \multicolumn{3}{|l|}{ Males (ns) } \\
\hline - July & 64 & 19.8 \\
\hline - $\quad$ August & 63 & 19.4 \\
\hline - September & 58 & 17.9 \\
\hline - October & 53 & 16.4 \\
\hline - November & 44 & 13.6 \\
\hline - December & 42 & 13.0 \\
\hline \multicolumn{3}{|l|}{ Non pregnant cows $* *$} \\
\hline - July & 260 & 19.6 \\
\hline - $\quad$ August & 205 & 15.5 \\
\hline - $\quad$ September & 207 & 15.6 \\
\hline - October & 179 & 13.5 \\
\hline - $\quad$ November & 263 & 19.9 \\
\hline - December & 210 & 15.9 \\
\hline \multicolumn{3}{|l|}{ Pregnant cows** } \\
\hline - July & 78 & 10.0 \\
\hline - $\quad$ August & 104 & 13.4 \\
\hline - September & 156 & 20.2 \\
\hline - October & 157 & 20.2 \\
\hline - November & 162 & 20.8 \\
\hline - December & 122 & 15.7 \\
\hline
\end{tabular}

$\mathrm{ns}=\mathrm{p}>0.05 ; * \mathrm{p}<0.01 ; * *=\mathrm{p}<0.001$.

Table 3: Prevalence of reproductive abnormities in slaughtered cows and associated factors.

\begin{tabular}{lllll}
\hline Health Status & No. of cases & Age (years) & Body condition Score & Prevalence (\%) \\
\hline Metritis & 20 & $8.2^{\mathrm{a}}(0.64)$ & $2.8^{\mathrm{ab}}(0.21)$ & 5.1 \\
Repeat breeders & 23 & $7.5^{\mathrm{ab}}(0.48)$ & $2.8^{\mathrm{ab}}(0.16)$ & 6.1 \\
Vagino-meritis & 3 & $8.7^{\mathrm{a}}(1.33)$ & $3.0^{\mathrm{ab}}(0.44)$ & 0.8 \\
Ovarian inactivity (Anoestrus) & 97 & $8.1^{\mathrm{a}}(0.29)$ & $2.2^{\mathrm{b}}(0.09)$ & 24.8 \\
Undeveloped uterus & 2 & $9.0^{\mathrm{a}}(1.6)$ & $2.5^{\mathrm{ab}}(0.54)$ & 0.5 \\
Other pathologies & 8 & $6.7^{\mathrm{ab}}(1.33)$ & $3.7^{\mathrm{a}}(0.44)$ & 2.1 \\
Normal fertile cows & $7.5^{\mathrm{ab}}(0.15)$ & $3.1^{\mathrm{ab}}(0.05)$ & 60.1 \\
Total & 237 & $7.33(2.52)$ & $2.9(0.83)$ & 100 \\
\hline
\end{tabular}

The means with superscript ${ }^{\mathrm{a}, \mathrm{b}}{ }^{\mathrm{et}}{ }^{\mathrm{ab}}$ are significantly different $(\mathrm{p}<0.001)$ to those of the same column. ${ }^{2}$ Other Pathologies (Mastitis, bed sore wound and intramuscular blood clots) 


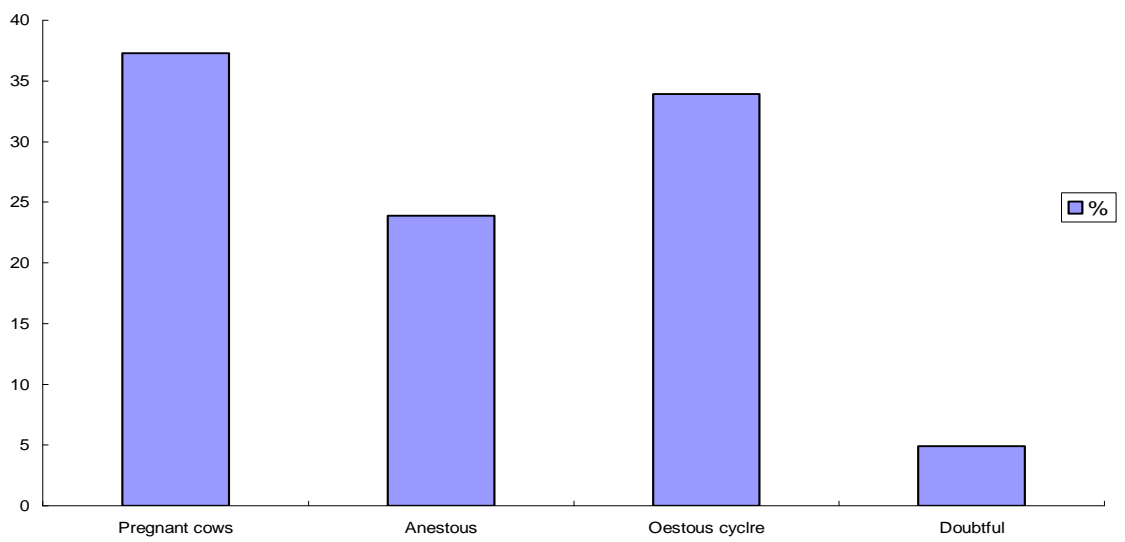

Figure 1: Distribution of slaughtered cows at the NMSH according reproductive cycle.

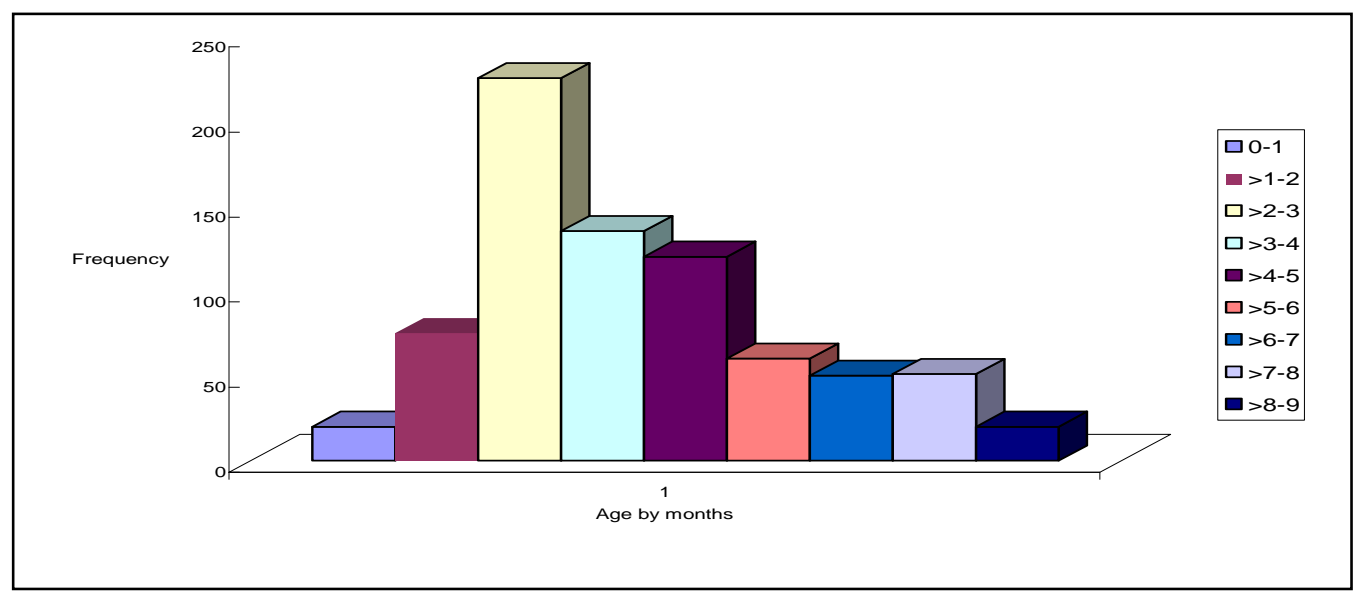

Figure 2: Distribution of foetuses recovered from slaughtered cows at the NMSH.

\section{DISCUSSION}

A high proportion of slaughtered cows at NMSH were below 9 years of age and more than half of the non pregnant cows were fertile as shown by the presence of follicular growth on their ovaries. The slaughter of pregnant or fertile cows as indicated in this study, signals a potential danger in the development of the cattle industry in Cameroon. With such trends the country can hardly meet up with its development objectives of the millennium fixed for 2015, with a targeted annual livestock growth rate of $2.5 \%$ (MINEFI, 2003).
The proportion (37.3\%) of pregnant cows slaughtered at the (NMSH) is lower than the 50\% reported by Ojo et al. (1978), for Nigeria, but higher than $16.6 \%$ reported levels in Yaoundé, Cameroon (Tchoumboue, 1988); and $22 \%$ in Bamenda, Cameroon (Ndi et al., 1993). Also, the projected numbers of 6,606 pregnant cows slaughtered at the NMSH is actually higher than the 5,654 reported for Nsukka, Nigeria (Wuso, 1988).

The Vina and Mbere Divisions of the Adamawa Region contribute $38 \%$ to the national meat need furnished by the Adamawa Region (MINEPIA, 2003). The number of 
animals slaughtered in the NMSH in 2004 estimated at 17,250 head is higher than the 16,414 registered for all the slaughter houses in Vina Division in 2003 (MINEPIA, 2003). This increase may be attributed to the increase in beef demand as a result of the rising increase of urban and high income population.

The proportion of slaughtered cows of $86.6 \%$ at the NMSH is higher than the proportion of $46.6 \%$ reported for the Adamawa Region (MINEPIA, 2003) and of $35 \%$ for Bamenda (Ndi et al., 1993). This can be attributed to the poor health status and fatigue associated with the animal's poor health situation, necessitating culling. These animals with an average body condition score of 2.3 can not withstand the stress of being transported over long distances to the southern part of Cameroon (MINEPIA, 2003). They are therefore slaughtered on the spot. This same report indicates that about $39 \%$ of slaughtered cows suffered from various illnesses. A high proportion $(24.8 \%)$ of the slaughtered cows suffered from anoestrous, a state which is indicative of infertility, or sterility, especially when associated with chronic metritis and nutritional deficiencies (Hafez, 1987; Hanzen, 2005). Anoestrous can also be associated with malformations of the reproductive organs (Hafez, 1987). The high proportion of cows in anoestrous slaughtered in the rainy season is an indication of the existence of pathologies of economic importance during this period. This also brings into light the inadequacies of the veterinary system in the country where farmers are left to themselves to handle animal health problems. However, further studies are necessary to identify the real causes of anestrous in the cows of the Adamawa Region.

About $83 \%$ of cows slaughtered in Ngaoundere were less than 9 years of age. But the age at first calving for the local breeds has been estimated at 4.5 years and the calving interval estimated at 18 months (Messine, 2003). Cows of this age are still productive for a number of years. It is therefore necessary for livestock farmers to know the reproductive status of their animals as to avoid the sale of fertile animals for slaughter. The high proportion of Gudali cows, about $76 \%$ slaughtered at the NMSH, is simply a confirmation of the fact that the Vina Division remains the exclusive zone (Decision $\mathrm{N}^{\circ}$ 013/MINEPIA of 31 May 994) for the rearing and conservation of this breed (MINEPIA, 2003). Also, the level of hybridization as a result of crossbreeding with other breeds is on the increase as indicated by the numbers slaughtered at the NMSH. This practice though may be detrimental on the long run (Ebangi et al., 2002; Tawah et al., 1999), could offer an alternative for increase beef and milk production in the Adamawa Region.

\section{Conclusion}

A high proportion of pregnant and fertile cows at active reproductive age are being slaughtered daily at NMSH. Infertility was responsible for one third of the slaughters made. Ovarian inactivity, metritis and vaginitis are causes of infertility that may spur the livestock farmers to sell cows for slaughter. It is, therefore, necessary to identify the causes of these pathologies so that control measures can be put in place to increase livestock population. The livestock farmer must be knowledgeable with simple methods to diagnose pregnancies as to reduce the percentage of fertile cows sold for slaughter. The government should equally make sure that the legislature forbidding the slaughter of pregnant cows is respected so as to decrease economic loses from the slaughter of PC and consequently contribute to increase in the bovine population in Cameroon.

\section{ACKNOWLEDGEMENTS}

This study received funding from the "Agence Universitaire de la Francophonie (LAF 309: 2003-2004)" and the government of Cameroon. We are grateful to the staff of the NMSH, Mr Joseph Nguini and Mr Haman Lazare of the Regional Centre of Agricultural Research for Development, Wakwa, for their assistance. The administrative support received for the study by The Chief of Centre 
of the Regional centre of Agricultural Research for Development, Wakwa, Dr Abba Dalil is highly acknowledged.

\section{REFERENCES}

Awa DN, Achukwi MD. 2010. Livestock pathology in the Central African region: some epidemiological considerations and control strategies. Anim. Health Res. Rev., 15: 1-10.

Ebangi AL, Erasmus GJ, Mbah DA, Tawah CL, Messine O. 2002. Factors affecting growth performance in purebred Gudali and two-breed synthetic Wakwa beef cattle in the tropical environment. Rev. Elev. Méd. Vét. Pays Trop., 55(2):149157.

Hafez ESE. 1987. Reproduction in farm animals $\left(5^{\text {th }}\right.$ edn). Lea and Febiger: Philadelphia; 107-129.

Hanzen CH. 2005. L'infertilité bovine: approache individuelle ou de troupeau? Le Point Vétérinaire, 36(Numéro spécial): 84-89.

Mertens H. 1987. Carnet clinique. Centre National de Formation Zootechnique et Vétérinaire de Maroua, $1^{\mathrm{e}}$ édition, p 29.

Messine O. 2003. Certain aspects of the reproductive performance of zebu cattle in Cameroon. PhD Thesis, University of the Free State, Bloemfontein, South Africa, p 200.

MINEFI. 2003. Poverty alleviation strategic paper. Department of Statistics Ministry of Economy and Finance, Cameroon.

MINEPIA. 2003. Rapport annuel d'activités; Exercice 2003. Délégation Provinciale de l'Adamaoua, Ministère de l'Elevage des Pêches et des Industries Animales, Cameroun, pp. 1-20.

Ndi C, Tambi NE, Agharih NW. 1993. Reducing calf wastage from the slaughtering of pregnant cows in Cameroon. World Animal Review, 77: 410.
Noakes D. 1986. Library of Veterinary Practice. Fertility and Obstetrics in Cattle (1st edn), Chandler EA, Bedford PGC, Sutton JB (eds). Blackwell Scientific Publications; 25.

Ojo SA, Denis SM, Leopold AG. 1978. Pregnancy in slaughtered cows in Zaria: relationship of age, season, stage of gestation and carcass weight. Nig. Vet. J., 7(1-2): 9-15.

SAS. 1991. SAS/STAT guide for Personal Computers. Version 6.03 edition. SAS Institute Inc. Cary N.C. (USA).

Tawah CL, Mbah DA, Messine O, Enoh MB, Tanya VN. 1999. Crossbreeding cattle for dairy production in the tropics: effects of genetic and environmental factors on the performance of improved genotypes on the Cameroon highlands. Animal Science, 69: 59-68.

Tchoumboue J. 1984. Calves lost through pregnant cows slaughtering. A particular case in Yaoundé abattoir. Rev. Elev. Méd. Vét. Pays Trop., 37(1): 70-72.

Tchoumboue J. 1988. Note sur l'abattage de brebis gestantes et les pertes d'agneaux au Cameroun. Revue d'Elevage et de Médecine Vétérinaire des Pays Tropicaux, 41(4): 461-462.

Tchoumboue J. 1989. Pertes de porcelets par abattage des truies gestantes au Cameroun. Revue d'Elevage et de Médecine Vétérinaire des Pays Tropicaux, 42(4): 589-590.

Wuso. 1988. Calf wastage through the slaughter of pregnant cows in Enugu abattoir Nigeria. Rev. Elev. Méd. Vét. Pays Trop., 41(1): 97-98. 